\title{
ASSESSMENT OF REED POTENTIAL FOR THERMAL ENERGY PRODUCTION IN LATVIA
}

\begin{abstract}
Anita VESPERE, Institute of Economics and Regional Development, Faculty of Economics and Regional Development, Latvia University of Agriculture, Svētes iela 18, Jelgava, Latvia; anita.vespere@inbox.lv (corresponding author)

Dina POPLUGA, , Institute of Economics and Regional Development, Faculty of Economics and Regional Development, Latvia University of Agriculture, Svētes iela 18, Jelgava, Latvia; dina.popluga@1llu.lv
\end{abstract}

Global challenges such as increasing population density and climate changes are putting focus on such emerging issues as transition to a green economy and mitigation of greenhouse gas emissions. Starting from 2021, activities in climate protection will be launched by the Paris Agreement, which provides not only for adapting to already occurring climate changes and reducing the expected effects but also promoting investment flows in a low carbon economy. In Latvia, one of the largest greenhouse gas emission sources is heat production from fossil fuel. Although biomass combustion generates about the same amount of carbon dioxide as fossil fuel, this is a friendlier source of energy because when it is restored, the carbon dioxide from the atmosphere is absorbed. Currently the most commonly used renewable source for the generation of thermal energy is wood. In the present research a theoretical study is conducted to assess the possibility of using another type of biomass - reeds, which is a common resource available throughout the country and recovers quickly. The research results showed that reeds can be used as an environmentally friendly alternative to firewood, but its efficient use should take into account the following factors: biomass with low humidity obtainable late in winter, the combustion process has a high ash level and before transporting, it should receive primary treatment to increase the bulk density and reduce transport costs. Reed as a separate fuel material is effective for solid fuel boilers, located close to the resource extraction site. An optimal use of this biomass source is possible in combination with other energy sources to produce pellets or briquettes.

Keywords: heat, renewable energy sources, reed, thermal energy

\section{INTRODUCTION}

Due to the increasing population density and climate changes, since 2012, the 'green economy' has been presented as a framework for climate mitigation, a new, 'green' driver for economic growth, and a tool for poverty alleviation (Buseth, 2017). The main idea of 'green economy' is to encourage technological and market-based solutions to environmental problems, like public and private investments that reduce carbon emissions and pollution, enhance energy and resource efficiency, and prevent the loss of biodiversity and ecosystem services(United Nations Environment Program, 2011). In addition starting from 2021, activities in climate protection will be launched by the Paris Agreement (Paris Agreement- Status of Ratification, 2017; Parīzes Nolīgums, 2016), which provides not only for adapting to already occurring climate changes and reducing the expected effects but also promoting investment flows in a low carbon economy. The purpose of a low carbon economy is to reduce greenhouse gas emissions as well as to increase $\mathrm{CO}_{2}$ sequestration or maintain the existing level of it.

There are many scholars that explore and examine the greening of energy production (Weber, Cabras, 2017; Cucchiella et al., 2017; Yong et al., 2016; Kuhlman et al., 2013) and bioenergy is considered as low-carbon energy source for potential, but whether bioenergy offer carbon reduction depends on how it is produced and applied (Jing, Peidong, 2011).Under the climatic conditions in Latvia, one of the most essential factors is thermal energy generation. Some of the fossil fuels are mainly used for thermal energy generation, e.g. natural gas, as well as wood. However, wood is not the only source of bioenergy, as any plant, the processing of which generates energy, could be a source of bioenergy. Although biomass generates approximately the same amount of carbon dioxide as fossil fuels, it could be considered to be an environment-friendly source of energy because every time new plants regrow, carbon dioxide is captured from the atmosphere (Li et al., 2009).

Regarding biomass as bioenergy feedstock it should be noted that eutrophication of water bodies and water ecosystem degradation were recognised as priority problems in Latvia. This means that the level of nutrients present in water bodies is too high, which results in poor water quality and the water bodies get overgrown (Latvijas ezeri aizauguši...,2012). The causes of nutrient over-enrichment could be diverse, e.g. sewage drained into water bodies, 
fertilisers used in agriculture as well as organic matterhaving entered the water bodies. In lakes and ponds in Latvia, reed stands occupy an area of more than 13 thousand hectares and the area continue increasing. In view of the fact that the source of bioenergy could be any kind of biomass, the authors examined the potential of reeds for thermal energy generation (Klimatapārmaiņucēloṇi un sekas, 2015; Čubars, 2014).In this context Kuhlman et al. (2013) argue that "cultivation of reed for bioenergy, in combination with providing additional land-use functions, may become competitive within the next twenty years" stating that this could be realistic if any of the following developments occur: energy prices increase substantially; water tables rise in the low-lying land parts of the country due to climate change; a policy is implemented that increases bioenergy prices; or a policy is implemented that stimulates water buffering and the preservation of peat soils.

Such situation analysis set aim for this study- to assess the reed potential for thermal energy production in Latvia. To achieve the set aim of this research, the authors have analysed the role of bioenergy in ensuring sustainable development, characterized reeds as a resource and described reeds as a source of renewable energy. The following materials were used in the research study: publications and studies of foreign and Latvian scientists, legislation, reports and recommendations. The research authors widely have applied generally accepted research methods in economics, i.e. monographic descriptive method, analysis and synthesis methods.

\section{RESULTS AND DISCUSSION}

\section{General characteristics and spread of reeds}

Common reed (Phragmites australis) is herbaceous plant of the grass family and is indigenous to Latvia (as well as in many parts of the world (Kuhlman et al., 2013)). It has a bare and slightly luminous stem. Its flower is a large, feathery, long panicle. Common reed has a creeping root and it propagates by the root parts - rhizomes. Common reed could be regarded as a dominant species. This means that if there are good conditions for growth, the spread of common reed is unconstrained and the plant can irreversibly change the typical fauna of a territory (Niedres, 2005; Parastā niedre, [s.a.]). Like in other European countries also in Latvia it is not normally cultivated, but for centuries it has been harvested in the wild as a raw material for handicrafts, roofing. Kuhlman et al. (2013) indicate that it is a prolific producer of biomass, both above and below ground; and since it is an inhabitant of wetlands, it holds promise for the alternative use of fens.

Common reed is one of the most widely distributed wetland plant genera worldwide occupying approximately ten million hectares (Köbbing et al., 2013). It is a highly productive grass with an above-ground net primary production ranging from less than $3 \mathrm{tha}^{-1} \mathrm{y}^{-1}$ to as much as 30 tha $^{-1} \mathrm{y}^{-1}$ (Allirand, Gosse, 1995). Reed can be found all over the world except in Antarctica, but its core distribution area is Europe, the Middle East and America (Köbbing et al., 2013).Table 1 presents data on the available amount of reeds in several European countries. The areas shown in Table 1 are approximate, since no statistical data on the available amount of reeds are collected and the production of reeds is not a popular kind of economic activity.

Table 1. Potentially available amount of reeds in European countries

\begin{tabular}{|l|l|l|c|c|}
\hline \multicolumn{1}{|c|}{ Territory } & \multicolumn{1}{|c|}{ Reed area, ha } & \multicolumn{1}{|c|}{ Year } & $\begin{array}{c}\text { Amount of biomass produced, } \\
\mathbf{t}^{-\mathbf{1}} \mathbf{h a}^{-\mathbf{1}}\end{array}$ & $\begin{array}{c}\text { Total amount of } \\
\text { biomass produced, } \mathbf{t}\end{array}$ \\
\hline Southern part of Finland & $30000(15000$ mowable $)$ & 2006 & 10 & 150000 \\
\hline Southern part of Sweden & 230000 & 2012 & 5 & 1150000 \\
\hline Great Britain & 7700 & 2013 & - & - \\
\hline Estonia & $27899(12970$ mowable $)$ & 2011 & 7 & 88368 \\
\hline Latvia (only lakes) & $13200(10826$ mowable) & 2010 & 7,20 & 69000 \\
\hline Lithuania (Curonian Lagoon) & 4995 & 2012 & - & - \\
\hline
\end{tabular}

Source: authors' summarization based on Köbbing et al., 2013

Table 1 contains statistical data on six European countries and the statistical data refer to various years; therefore, the data are not comparable. If assuming that no significant changes in the reed areas occurred, one can find that any of the selected countries have the potential for the production of reeds as a resource. The available amount of the resource is determined by a number of factors: the total area of a country, the area of wetlands, the area of specially protected natural territories, requirements for the management of water bodies etc.

Regarding common reed distribution in Latvia in 2014 by employing method of remote land surveying, researcher Edgars Čubars from Rezekne Academy of Technologies estimated that the total area under reed stands at 13400 hectares and the annual biomass of reed at 97 thousand tonnes. The reed stands grow across the entire territory of Latvia. However, larger areas under reeds are observed in lagoon-type lakes, as such lakes are shallow, with flat banks (Table 2).

This means that the mentioned sites are the most appropriate territories for the production and use of reeds. It is not possible to harvest the entire reed area, which ensures a sustainable use of this resource. It is possible to harvest not more than $50 \%$ of the total reed stand area in order not to make a negative impact on a reed stand and the organisms living there, and the same area could be harvested every two years. If the purpose is to limit or reduce the spread of reeds, the reeds could be mowed more frequently. Accordingly, the really available amount of dry matter of reeds in Latvia is estimated at 32000 tonnes. In Latvia, thirteen territories could be referred to as potential reed production zones (Čubars, 2014). 
Table 2. Priority reed production zones and their potential in Latvia

\begin{tabular}{|c|l|c|c|}
\hline No. & \multicolumn{1}{|c|}{ Potential reed production zone } & $\begin{array}{c}\text { Really available area under } \\
\text { reeds, ha year } \mathbf{- 1}\end{array}$ & $\begin{array}{c}\text { Really available amount of reed } \\
\text { dry matter, t year }\end{array}$ \\
\hline 1 & Lake Engure & 1600 & 6800 \\
\hline 2 & Lake Pape & 1040 & 5800 \\
\hline 3 & Group of lakes around Lubana & 570 & 3800 \\
\hline 4 & Lakes Liepaja and Tosmare & 620 & 3200 \\
\hline 5 & Group of lakes around Rusona & 365 & 2000 \\
\hline 6 & Lake Burtnieki & 220 & 1300 \\
\hline 7 & Lake Babite & 250 & 1200 \\
\hline 8 & Lake Kanieris & 215 & 1100 \\
\hline 9 & Lake Razna & 145 & 900 \\
\hline 10 & Group of lakes around Ludza & 100 & 550 \\
\hline 11 & Lake Kisezers & 85 & 460 \\
\hline 12 & Lake Lobe & 75 & 440 \\
\hline 13 & Lake Lielauce & 55 & 200 \\
\hline
\end{tabular}

Source: authors' summarization based on Čubars, 2014

Due to the effects of various factors, the available amount and quality of reeds could differ within even one water body. A comparison of potential reed production sites in terms of biomass characteristics shows that the highest potential is in the lakes and ponds of Latgale region where, on average, seven tonnes of reeds could be harvested per hectare. In contrast, in the coastal region, reeds are less common, shorter and thinner, and the amount of biomass to be harvested is about two tonnes per hectare (Jansone, 2012; Köbbing et al., 2013). Such situation analysis led authors' to conclude that common reed holds potential to be used as biomass feedstock for bioenergy production as average annual amount of dry matter to be harvested totals approximately 32000 tonne. However, in order to promote efficient use of reeds as a resource, authors' believe that special amendments should be made in legislation addressing management of water bodies, as the lack of management of reed stands (no mowing operations) in protected nature territories can contribute to the degradation of the territories.

\section{Use of reeds for thermal energy production}

Reeds as a resource is available in various amounts almost worldwide. In Latvia too reeds are available in the entire territory and have several uses, as the reeds are used not only as a feedstock for industry but also in agricultural activity and energy production (see Figure 1).

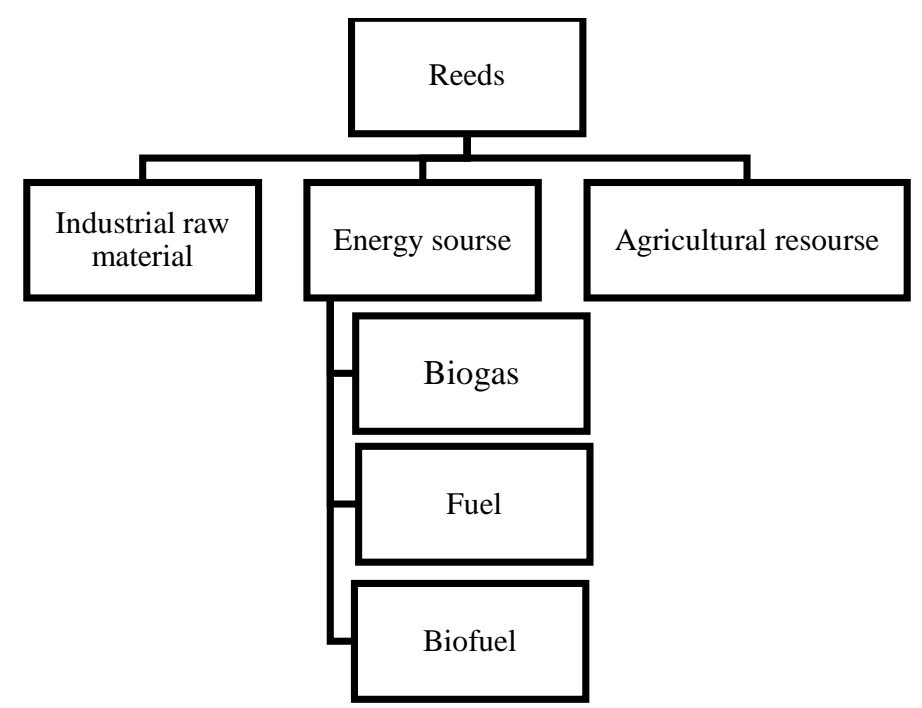

Source: authors' construction based on Köbbing et al., 2013

Figure 1. Potential uses of reeds as a resource

Historically, reeds were used as an industrial resource (in crafts and as a roofing material). The authors believe that these two uses cannot consume the available amount of reeds, therefore an alternative use should be sought. Energy production is one of the alternatives.

The productivity of reeds, just like that of other renewable sources of energy, depends on seasonality. Cubars (2014) indicate that on an annual basis, the production of reeds is affected by the following most significant factors:

- the water body factor - the characteristics of a particular water body. The key characteristics are the kinds and levels of nutrients that are available in the water body.

- $\quad$ weather conditions: temperature, precipitation, wind direction and strength; 
- $\quad$ production sites - reed quality characteristics are different even within one water body. This could be explained by differences in ground for reed growth, water depth in various sites, river sources and estuaries, the amount of nutrients having entered the water body;

- $\quad$ production intensity - the reed-mowing effect could be assessed in two periods: in a long-term, more than ten years, and in a short-term -two or three years. According to research studies, if reeds are not mowed for a long period, the amount of reed biomass produced is smaller than if mowed periodically in a short period.

The natural moisture content of reeds if mowed in winter is in the range of 8-12\% (Kronbergs, Šmits, 2009). This means that no drying is needed before using the reeds as a fuel. The average energy content of reeds is $14 \mathrm{MJ} / \mathrm{kg}$ (Köbbing et al., 2013). The bulk density of reeds is low, $20-60 \mathrm{~kg} / \mathrm{m}^{2}$, which means that the transport and storage of reeds require more resources than that of other denser sources of energy. As regards the use of reeds, a solution could be compactionshredding and pressing. This operation has to be done as closely to the reed production site as possible, thereby reducing transport cost. Besides, compaction facilitates the use of reeds in thermal energy production because combusting loose biomass requires a special furnace equipped with an adapted reed feed and ash removal system. The compaction of reed biomass could be done by the same techniques as the pelleting of wood. To reduce transport and storage costs, it is advised that the bulk density of the final product is less than $1.0 \mathrm{~kg} / \mathrm{dm}^{3}$. This could be achieved in two ways:

- the shredding process has to ensure that the size of a reed fraction is less than $0.5 \mathrm{~mm}$;

- larger size fractions have to be supplemented with, e.g. peat that fills in empty space among the fractions of reed stems. A 30\% peat supplement can ensure an optimum bulk density of the biofuel. Furthermore, combining the substances can not only increase the density of pellets but also improve combustion properties of the biofuel (Kronbergs, 2001).

In sustainable development, focus has been placed on a low carbon economy; for this reason, the average carbon content of fuels was taken into consideration as one of the factors when analysing energy sources. As shown in Figure 2, compared with the other fuels, the carbon content of reeds expressed in percentage terms does not differ considerably.

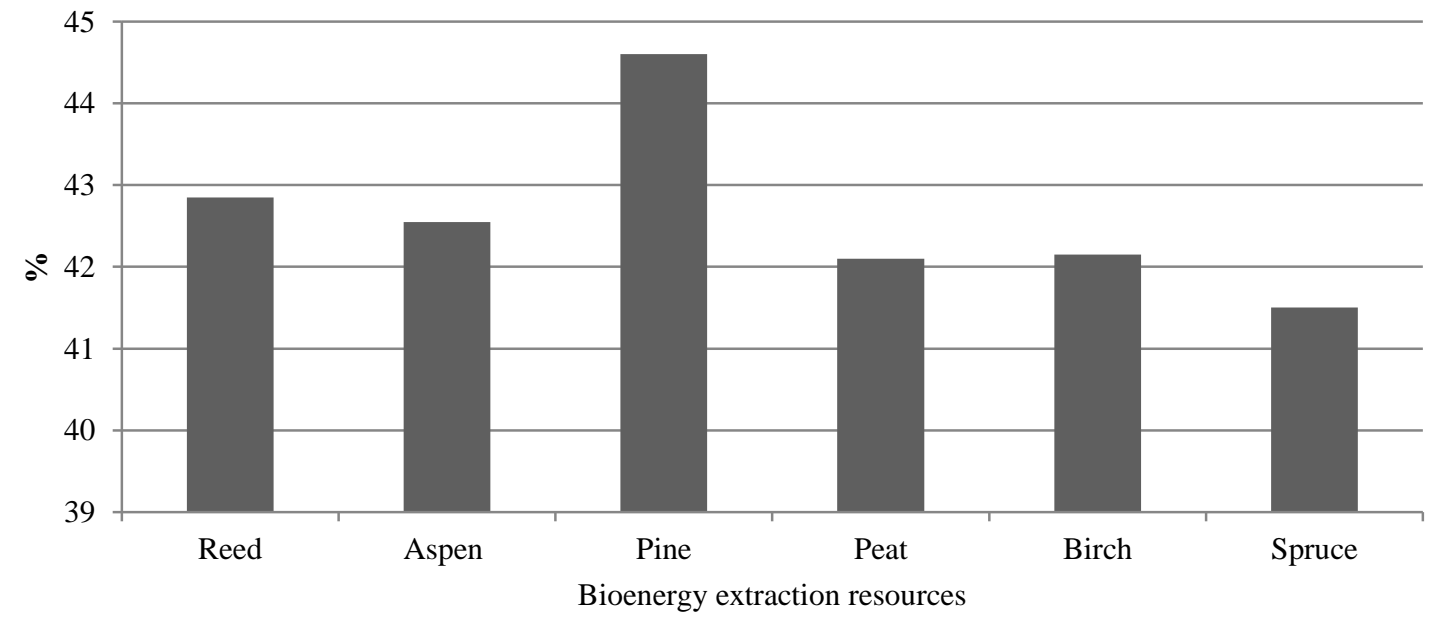

Source: authors' construction based on Čubars, Noviks, 2009

Figure 2. Average carbon contents in different bioenergy extraction resources, \%

However, a highash content is characteristic of reeds. For this reason, straw-burning furnaces have to be used to achieve complete combustion and an efficient use of reeds. Standard furnaces equipped with extra equipment or pretreated reed fuel could be the alternatives (Čubars, Noviks, 2009). This, however, limits opportunities to use reeds as a biofuel. Authors' consider that reeds as a resource have to be used complexly - the reeds of adequate quality have to be used as a roofing material and in crafts or for the production of insulation materials. Reed production by-products or lowquality reed products have to be used as a source of energy. Reeds have to be shred and combined with other sources of energy, i.e. wood or peat. By producing pellets comprising the dry matter of peat and reed, it is possible to achieve a higher bulk density and better combustion properties than if no supplement is added.

\section{CONCLUSIONS}

Reeds as a resource is available in the entire territory of Latvia and total area under reeds exceeds 13000 hectares. This show that common reed holds potential to be used as biomass feedstock for bioenergy production as average annual amount of dry matter to be harvested totals approximately 32000 tonne. However, in order to promote efficient and sustainable use of reeds as a resource, special amendments should be made in legislation addressing management of water bodies.

Reeds are an appropriate source of energy because carbon content of reeds does not differ much from that of wood or peat because, however reed has high ash content, which means that reeds have to be shred and combined with other sources of energy, i.e. wood or peat. As energy resource reed has several advantages: harvested in winter, the moisture 
content of reed dry matter is adequate and there is no need to dry the reeds; reed regenerates fast, compared with, e.g. wood. Though factors constraining reeds as a source of energy should be taken into account: production seasonality, necessity to adapt boiler equipment to the use of reeds and the low biomass bulk density of reeds before pre-treatment.

\section{REFERENCES}

1. Allirand, J.M., Gosse, G. 1995. An above ground biomass production model for a common reed (Phragmites communis Trin.) stand. Biomass and Bioenergy, Vol. 9, Iss. 6, pp. 441-448. https://doi.org/10.1016/0961-9534(95)00042-9

2. Buseth, J.T. 2017. The green economy in Tanzania: From global discourses to institutionalization. Geoforum, Vol. 86, pp. 42-52. https://doi.org/10.1016/j.geoforum.2017.08.015

3. CucchiellaF., GastaldiM., TrosiniM. 2017. Investments and cleaner energy production: a portfolio analysis in the Italian electricity market. Journal of Cleaner Production, Vol. 142, pp. 121-132. https://doi.org/10.1016/j.jclepro.2016.07.190

4. Čubars, E. 2014. Niedru produktivitāti un biomasas īpašību ietekmējošo faktoru izpēte un to izmantošana enerǵijas ieguvei pamatojums (Factors Affecting the Productivity and Biomass Properties of Reeds and the Feasibility of Energy Production from Reed) Available at: http://www.rta.lv/uploads/source/content_LV/zinatne/doktorantura/promocijas_darbu_kopsavilkumi/KopsavilkumsA4\%20E_C ubars.pdf (Accessed on10/04/2017) [In Latvian]

5. Čubars, E., Noviks, G. 2009. Lubāna ezera niedru resursu izvērtēšana un to izmantošana enerğijas ieguvei pamatojums (Estimation of Reed Resources of the Lake Lubans and the Feasibility of Energy Production from Reed). Proceedings of the 7th International Scientific and Practical Conference "Environment. Technology. Resources", Vol. 1, pp. 66-73. [In Latvian]

6. Jansone, A. 2012. Latvijas ezeri aizauguši ar niedrēm 13 tūkstošu hektāru platībā (Lakes in Latvia are Overgrown with Reeds in the Area of 13 Thousand Hectares). Available at: http://www.varam.gov.lv/lat/aktual/preses relizes/?doc=15037 (Accessed 23/5/2017) [In Latvian]

7. Jing, Y., Peidon, Z. 2011. Assessment methods of carbon dioxide emitted from bioenergy utilization. Renewable and Sustainable Energy Reviews, Vol. 15, pp. 2684-2689. https://doi.org/10.1016/j.rser.2011.02.028

8. Kuhlman, T., Diogo, V., Koomen, E. 2013. Exploring the potential of reed as a bioenergy crop in the Netherlands. Biomass and Bioenergy, Vol. 55, pp. 41-52. https://doi.org/10.1016/j.biombioe.2012.06.024

9. Klimata pārmaiṇu cēloṇi un sekas. 2015. (Causes and Effects of Climate Change). Available at: https://www.youtube.com/watch?v=TQP-5Ggio4U (Accessed on 25/02/2017) [In Latvian]

10. Köbbing, J.F., Thevs, N., Zerbe, S. 2013. The Utilisation of Reed (Phragmites Australis): a Review. Available at: http://miresand-peat.net/media/map13/map 13 01.pdf (Accessed on10/04/2017) [In Latvian]

11. Kronbergs E. 2001. Biomasas kompaktēšnas iespējas (Possibilities to Compact Biomass) Available at: http://journals.ru.lv/index.php/ETR/article/view/1935/1943 (Accessed on 10/04/2017] [In Latvian].

12. Kronbergs, Ē., Šmits, M. 2009. Energ̊ētisko augu kondicionēšana bioenerǵijas ieguvei (Conditioning Energy Crops for Bioenergy Production) Available https://www.researchgate.net/profile/Eriks Kronbergs/publication/282470406 Conditioning of energy crops for bioenergy production/links/5804c0dc08ae0b2b3ef440f6.pdf (Accessed on 11/04/2017). [In Latvian]

13. Latvijas ezeri aizauguši ar niedrēm 13 tūkstošu hektāru platībā (2012) (Lakes in Latvia are Overgrown with Reeds in the Area of 13 Thousand Hectares). Available at: http://www.reitingi.lv/lv/archive/daba/64809.html (Accessed on 12/04/2017) [In Latvian]

14. Li, S.L., Wang, Y.H., Song, W.M. 2009. Function of developing forest biomass energy on reducing carbon dioxide. Journal of Northeast Forestry University, Vol. 37, Iss. 4, pp. 83-85.

15. Niedres, 2005. Meža enciklopēdija. (Reed. Forestry Encyclopaedia) Available at: http://www.letonika.lv/groups/default.aspx?cid=36579\&r=7\&lid=36579\&q=\&h=0 [In Latvian]

16. Parastā niedre [s.a.]. Available at: https://www.latvijasdaba.lv/augi/phragmites-australis-cav-trin-ex-steud/ (Accessed on 26/04/2017)

17. Paris Agreement-Status of Ratification. 2017. Available at: http://unfccc.int/paris_agreement/items/9444.php (Accessed on 13/03/2017)

18. Parīzes Nolīgums (2016) Eiropas Savienības Oficiālais Vēstnesis (Paris Agreement. Official Journal of the European Union)[online][accessed 11 March2017]. Available ht: htt//eur-lex.europa.eu/legalcontent/LV/TXT/PDF/?uri=CELEX:22016A1019(01)\&from=LV

19. United Nations Environment Program. 2011. Towards a Green Economy: Pathways to Sustainable Development and Poverty Eradication (Accessed on 23/01/2018)

20. Yong, J.Y., Klemeš, J.J., Varbanov, P.S., Huisingh, D. 2016. Cleaner energy for cleaner production: modelling, simulation, optimisation and waste management. Journal of Cleaner Production, Vol. 111, pp. 1-16. https://doi.org/10.1016/j.jclepro.2015.10.062

21. Weber, G., Cabras, I. 2017. The transition of Germany's energy production, green economy, low-carbon economy, socioenvironmental conflicts, and equitable society. Journal of Cleaner Production, Vol. 167, pp. $1222-1231$. https://doi.org/10.1016/j.jclepro.2017.07.223 